\title{
Anarchism and the Myth of the Primitive: Godwin and Kropotkin ${ }^{1}$
}

\author{
by Samuel Clark
}

First published in Studies in Social and Political Thought 15, 2008.

\section{Abstract}

Anarchists are commonly assumed to hold deeply optimistic views about human nature, and to be nostalgic for 'primitive' (as opposed to 'civilised') societies. I shall argue here not only that these assumptions are false but also that it is worthwhile revealing them as such, both as a means of recovering some interesting thought from misrepresentation, and because a more precise account of primitivism is useful in other contexts.

\section{Introduction}

'Traditionally, anarchists are seen to possess an optimistic conception of human nature, an optimism essential to the success of their vision of a Stateless society' (Morland, 1997: vii) For example, according to James Joll '[ $t$ ]he fundamental idea that man is by nature good and that it is institutions that corrupt him remains the basis of all anarchist thought' (1979: 16). For Joll then, anarchists share the mental pathology of heretical Christians who demand and expect 'a return to the Golden Age of the Garden of Eden before the Fall' (Ibid.: 6). Similarly, Roger Scruton claims that 'typical anarchist beliefs' include that 'men are benign by nature and corrupted by government' (1983: 15). For Irving Horowitz 'Anarchism has as its theoretical underpinning an idealization of natural man in contrast and in opposition to civilized man .... What is offered is a belief in "natural man" as more fundamental and historically prior to "political man"' (1964: 16). Finally, Norman Barry argues that 'Communitarian [as opposed to libertarian] anarchism depends upon an optimistic view of human nature as essentially benign and cooperative' (1991:5). These examples could easily be continued and all impute one or both of two claims to anarchists: that they believe, first, 
in a pure and good human nature which is distorted or masked by current circumstances; second, in a long-lost golden age. In sections one and two below I set out these claims in more detail, and then show how in each case they do not apply to two representative anarchists, William Godwin and Peter Kropotkin.

Claims that anarchists are primitivists have often been used to ground wider criticism of anarchist thought. Robert Dahl, for instance, offers as 'a critique of anarchism' the thought that 'while some romantic anarchists may imagine our returning to the tiny autonomous groups of some preliterate societies, short of a cataclysm that no sane person wants, a return to the infancy of the species looks to be impossible or, if not impossible, highly undesirable' (1989: 43; 46). Benjamin Barber attacks anarchists because 'their view of actual men is wildly romanticized. Hunger, greed, ambition, avarice, the will to power, to glory, to honour, and to security which have played some role in all traditional ethnologies find no place in the anarchist portrait of man' (1972: 18). Barber directs this attack specifically against twentiethcentury American anarchists such as Abbie Hoffman, but is explicit that he believes the entire tradition from Godwin onwards to be implicated in this 'wild' romanticism. His evidence in fact consists of unsupported claims about the elitist psychology of individual anarchists and a few, out-ofcontext quotations. Similarly, the only support Horowitz can give for his characterisation (quoted above) comes from Denis Diderot, who, in Horowitz's own words, 'advocated a parliamentary monarchism in which representation would be elected by the propertied classes' $(1964 ; 65-6)$ and was therefore clearly not an anarchist. In the face of evidence this weak, it is tempting to dismiss the whole line of attack as a self-sustaining polemic. However, there are two forms of this criticism which require a more detailed response; I call them accusations of 'primitivism,' for convenience and because each can be related to one of the various meanings of 'primitive.'

'Primitive' is a complex term: it can mean unsophisticated, savage, stupid or childish; pure; original or primary; low or simple; an early stage of evolution or progress; a relic or survival in a world that has moved on. It can refer to people or societies without technology or without institutions; 'primitive' here stands in a complex relation to a cluster of terms including 'savage,' 'native,' 'aboriginal,' 'undeveloped,' 'un-evolved' and 'prehistoric,' and also to opposing terms like 'civilised,' 'developed,' 'complex,' 'sophisticated' and 'modern'. We should note the term's ideological weight: calling societies or people 'primitive' has often been involved in, and even stood in for, justifications of marginalisation, oppression and extermination. It can also be used in a less extreme but still polemical way, to indicate a comfortable value judgement: 'we are civilised, they are primitive.' The two 
meanings of the term which relate to the criticisms of anarchism under discussion here are primitive as that which is pure, and primitive as being original or primary. The criticisms which involve these meanings are, respectively: the claim that anarchism depends on an unrealistic notion of uncorrupted human nature ('human nature primitivism'); and the claim that anarchists are nostalgic for a mythical golden age ('golden age primitivism'): I define and respond to each in turn.

\section{Anarchism and Human Nature Primitivism}

Ideas of human nature are various, important and contested, including for instance Christian, liberal, conservative individualist, Rousseauian, Darwinian, Freudian, existentialist and feminist human natures (see Chaney, 1990; Loptson, 1995; Stevenson and Habermaru 1998). Such conceptions are important because so much can depend on them, for an individual the answer to the question about the human nature she shares will shape how she understands the meaning of her life, what she ought to do, what she might be able to achieve or become, and what limits she must respect or accept. For groups, it will shape our understanding of our history, the changes we ought to make, and the vision of the future we can reasonably hope to realise: that is, ideas of human nature are important because very different and often very powerful individual and political aims and understandings are based on different accounts of human nature. They are also important because claims about human nature entail an often effective means of criticism, both of current arrangements and of schemes for their reform: current arrangements can be condemned as corrupting or as not living up to the best in human nature; suggested reforms, as not taking the constraints of human nature into account. Ideas of human nature are contested because of both their variety and their importance. Human nature is the locus of a continuing argument, both in its own right and as a battleground of ideologies which involve particular claims about it. Existentialist and other negative claims about human nature (at the limit, that there is no such thing) can also perform these functions of grounding aims and analysis, and of criticism.

Historically and typically, an idea of human nature is a set of claims that a specified character: is real or permanent or transhistorically present in humans; is shared by all humans; distinguishes humans by kind, and not merely by degree, from the rest of the world, and especially from (other) animals; is separate from the distortion and masking which can be created by current circumstances; and stands as a moral, social or political norm for all humans. These five components are not necessarily connected. What is real 
or permanent, rather than merely apparent or transitory, in an individual human might not be shared by all or only other humans. What is shared by all humans might not have any normative force. What distinguishes humans from other animals might be the distortion caused by current circumstances. However, these five claims do form a group which repeatedly appears in the history of thought. Different ideas of human nature make this set of claims about different characters; negative ideas deny that some or all of them are true of any character. Some ideas have both positive and negative elements: some post-Darwinian thinkers, for instance, have made the negative claim that humans are not distinct in kind from other animals, because all evolved by natural selection, and the positive claim that what is shared by all such creatures is being vehicles for 'selfish genes' (see Dawkins, 1989).

If anarchists are human nature primitivists, then their shared idea of human nature must be that what is real, permanent, ahistorical, shared, distinguishing, separate and normative in humans is a nature which is wholly pure and good. That is, which is virtuous, benevolent, altruistic, reasonable, peaceable, cooperative or loving (or some combination of some or all of these), and not vicious, malicious, selfish, irrational, aggressive or hateful. Even if this is the anarchist idea of human nature, this is a criticism of anarchism only if it is inaccurate, and its inaccuracy renders it unusable as a norm. The second criterion is needed because the fact that a claim or story is literally false does not, by itself, disqualify it as morally useful: it need not be the case that someone called Raphael Hythloday really visited a place called Utopia for the idea of Utopia to be a standard of criticism for the real world. Similarly, that an account of human nature is literally false does not necessarily mean that it is unusable. There are therefore three ways of defending anarchism against the critical accusation of human nature primitivism: first, to show that anarchists do not, in fact, share that idea of human nature; second, to show that the idea is true; or, third, to show that although it is false, it is still useful as a moral, social or political norm. I take the first path, and defeat the accusation by counter-example.

Some anarchists think it enough, when stating their views on human nature, to distance themselves from other anarchists who, they suppose, do hold the primitivist view. Jacques Ellul, for instance, distinguishes himself from (what he believes to be) mainstream anarchism on two grounds: he is a Christian, and he does not believe that 'an anarchist society - with no state, no organisation, no hierarchy, and no authorities — is possible' (1991: 19). This 'anarchist vision or hope of a society with neither authorities nor institutions rests on the twofold conviction that people are by nature good and that society alone is corrupt' (Ibid.), but Ellul does not accept such a 
primitivist account of human nature; he thinks that the 'anarchist fight' (Ibid.) is worth fighting, but that its goal is unreachable, because of flawed (that is, fallen) human nature. Ellul shows that his Christianity distinguishes him from other anarchists with a concrete example: Guy Debord and his situationist comrades refused to let him join: 'since I was a Christian I could not belong to their movement' (Ibid.: 3). But in the case of Ellul's view of human nature, the parallel evidence is unsupported attribution of the view with which he disagrees to the un-named 'true anarchist' (Ibid.; 19).

Other anarchists, writing before the accusation of human nature primitivism became widespread, simply state quite different ideas of human nature. The accusation is the generalisation that anarchists, as a group, share and use the particular idea of human nature defined above. One counterexample is enough to falsify a generalisation, but to make the point more strongly, and for further reasons which will become clear below, I give two: the ideas of human nature in the work of William Godwin and of Peter Kropotkin.

William Godwin was born in 1756, was brought up as a Calvinist, and initially followed his father and grandfather into Independent ministry. During periods as minister to congregations in Ware, Stowmarket and Beaconsfield, he lost or transformed his faith. He moved to London in 1782, and would spend the rest of his life there, supporting himself by writing novels, plays, political journalism and philosophy. He married Mary Wollstonecraft in 1797, when she became pregnant (they had been openly a couple, although maintaining separate households, for some years previously). She died a few days after giving birth to their daughter Mary, later Mary Shelley. Godwin lived until 1836, and gradually modified or repudiated much of the radicalism of his earlier work (see Godwin, 1992; Marshall, 1984; 1986: 9-48; St Clair, 1989; Woodcock, 1946).

Enquiry Concerning Political Justice, first published in 1793, made Godwin first famous, then caricatured, and finally, in combination with his frank memoirs of Wollstonecraft, reviled. It presents several problems of interpretation, the first of which is how to understand its project and claims as a whole. It can be read as utilitarian; as extreme rationalist; as the effort of a lapsed Christian to restate his faith in secular terms; as a celebration of the French revolution; as an abstract mirroring of working-class social radicalism; as a product of the enthusiasm of a recent convert to enlightenment atheism and determinism; as the philosophical expression of beliefs current in the intellectual and social circles of late-eighteenth century Rational Dissenters; and finally as the bible of anarchism. ${ }^{2}$ I shall not attempt a resolution of these tensions: what is important here is the idea of human nature which the book asserts. 
Godwin's idea of human nature is twofold, and essentially critical. He makes two claims, and the point of each is that it refutes an objection to his prescription for and prediction of future human sociability:

I shall attempt to prove two things; first, that the actions and dispositions of mankind are the offspring of circumstances and events, and not of any original determination that they bring into the world; and, secondly, that the great stream of our voluntary actions essentially depends, not upon the direct and immediate impulses of sense, but upon the decisions of the understanding (1985: 97).

That is, first, 'the characters of men originate in their external circumstances' (Ibid.: 96), and not in any innate characteristics; second, 'our prospects of melioration depend on the progress of enquiry and the general advancement of knowledge' (Ibid.: 116). Knowledge is motivating; 3 future knowledge about human good will motivate people to act for it; and there are no bars to the gradual creation of people capable of this radical transformation of human life. This means that through progress in moral, social and political science, through the exercise of individual judgement, and through the consequent transformation of human thinking and political institutions, Godwin's anarchic utopia is realisable. That this claim is perhaps unconvincing is irrelevant here: according to the accusation of human nature primitivism anarchists are supposed to hold a particular idea of human nature, but Godwin's stated idea is utterly unlike it. For him, the only things which are permanent and shared in humans are the absence of innate limitation and the possibility of true and motivating judgement. This conception of human nature does moral and political work only in that it supports the practical possibility of a utopia of rational, sincere, mutually censorious neighbours working, without partiality but using their own individual judgement, for universal human flourishing. That utopia does further work in providing both a target for social change, and a critical comparison with current arrangements. Godwin not only makes no assertions about the innate purity and goodness of humans, but explicitly denies that any such claim could be true. ${ }^{4}$ For Godwin, 'pure' humans exist only in the imagined future, and only then as a result of the transformation of current humans, and their institutions, by the progress of knowledge. Anarchists are supposed to be human nature primitivists: but the Godwin of Enquiry, at least, was not. We have our first counter-example.

Peter Kropotkin was born in 1842, a younger son of the Russian aristocracy. A geographer, naturalist and mathematician, at nineteen a 
personal page of Tsar Alexander Il, and in the 1860s a military administrator in Siberia, he repudiated his privilege and scientific career to become a revolutionary, political exile and anarchist writer. The major influences on his life and theory were his older brother Alexander; the serfs on his family estate; the socialist movements, and in particular the Bakuninite Jura Federation, which he encountered in Europe; and, most importantly here, Charles Darwin, as understood through the Russian evolutionist tradition which rejected Darwin's Malthusian metaphor of Individualist struggle. ${ }^{5}$

Kropotkin approaches the idea of human nature in two main ways: as a defender of the possibility of anarchism and communism, and as a Darwinian naturalist. In the first case, Kropotkin notes that a common objection to 'communism, and socialism altogether' is that:

the idea is so old, and yet it has never been realised. Schemes of ideal states haunted the thinkers of ancient Greece; later on, the early Christians joined in communist groups; centuries later, large communist brotherhoods came into existence during the reform movement. Then, the same ideals were revived during the great English and French Revolutions; and finally, quite lately, in 1848, a revolution, inspired to a great extent with socialist ideals, took place in France. 'And yet, you see,' we are told, 'how far away is the realization of your schemes. Don't you think that there is some fundamental error in your understanding of human nature and its needs?' (Kropotkin, 1995: 4).

We might expect a human nature primitivist to respond to this pseudohistorical derivation of an idea of human nature - the idea that it renders us incapable of communism - with a positive counter-assertion. We might expect an anarchist primitivist to reply that real, pure and good human nature, which is capable of anarchist communism, has been corrupted and thwarted by state reaction. Kropotkin does nothing of the sort. Instead, he suggests a more careful reading of history, which leads him to argue that 'hundreds of millions of men have succeeded in maintaining amongst themselves, in their village communities, for many hundreds of years, one of the main elements of socialism - the common ownership of the chief instrument of production, the land, and the apportionment of the same according to the labour capacities of the different families' (Ibid.). The historical evidence does give partial support to the possibility of communism, and certainly does not support the sweeping anti-communist generalisation about human nature and its potential. So, 'all we are 
authorized to conclude is, that mankind has not yet found the proper form for combining, on communistic principles, agriculture with a suddenly developed industry and a rapidly growing international trade' (Ibid.: 5). Far from asserting any permanent characteristic of human nature, Kropotkin tentatively interprets the empirical evidence of human history. His interest is not in such permanent characteristics at all, but in some temporary, changing and potentially changeable features of human social activity, as they have appeared. Human nature appears only in a criticism of communism, in order that Kropotkin can refute it. This concern with history, and with the tentative conclusions that can be drawn from it, runs throughout his work.

In the second case, Kropotkin approaches human nature as a naturalist and Darwinian. In his theory, humans are seen as part of the wider natural world, and in Mutual Aid ${ }^{6}$ attempts to show that cooperation within a species, including the human species, is a major factor in evolution (but not, as has sometimes been asserted of him, the only factor; Kropotkin wanted to correct Thomas Huxley's over-emphasis of a gladiatorial struggle for existence). The details and force of this argument are not relevant here, what is important is that far from asserting a permanent and pure human nature, Kropotkin uses detailed empirical evidence of change and its causes to derive tentative conclusions about current humans and their social characteristics. He presents humans as part of the wider and changing system of nature. ${ }^{7}$ In an evolutionary world, there can be no human nature in the strong sense defined above, because nothing is permanent or transhistorically present in humans. Kropotkin is interested in what humans and other creatures have come to be, and how. His central conclusion is that humans, as they have evolved, have tendencies both to egalitarianism and mutual aid (good characteristics, for him) and to hierarchy and selfishness (bad ones). That is, that we are not wholly pure and good, but have both good and bad tendencies, "now the one and now the other taking the upper hand at different periods of history' (Kropotkin, 1911: 233-47; 236). Kropotkin is not particularly interested in permanent, shared, distinguishing, separate and normative characteristics in either of his approaches to human nature. Nor does he assert that human nature is pure and good. Instead he investigates the nature of current humans as an empirical fact and as a moment in a long transformation, discoverable by research in biology and history, and admitting only tentative conclusions. We have our second counter-example to the generalisation that anarchists are human nature primitivists: Kropotkin emphatically was not.

It is unlikely that partisans of the accusation of human nature primitivism literally and formally mean the generalisation that 'all anarchists 
are human nature primitivists'. If any do, they have been proved wrong twice over, unless they are prepared to argue that neither Godwin nor Kropotkin was really an anarchist. If, as is more likely, they mean only that most anarchists are human nature primitivists, or that anarchism tends to partake of such primitivism, then the formal way to test their claim would be to go through all anarchists, testing each. ${ }^{8}$ But how are we to list 'all anarchists'? The two counter-examples given above must, at least, throw doubt on the accusation: Godwin and Kropotkin are widely recognised to be among the most important of anarchism's theorists, and if they were not human nature primitivists then stronger evidence will be needed to make the general accusation and derived criticisms stick. In the absence of that further evidence, we must accept that anarchists are therefore not, in general, human nature primitivists.

\section{Anarchism and Golden Age Primitivism}

'Golden age' primitivism centres on a value claim about a picture of human historical development. In this picture, humanity or human society are envisioned as having changed from some primary, natural or foundational state to some elaborated or artificial one. This change is understood as both qualitative and quantitative: the qualitative change, at its simplest, is from 'primitive' to 'civilised,' but has also been further divided in various ways; the quantitative change is typically measured on a scale of complexity (from simple to complex) or of height (from lower to higher forms), or both. Various kinds of evidence can be used to characterise the primary state, but most often the theorist will use historical and archaeological evidence about past social forms, or anthropological evidence about current social forms which are conceived as relics of the primary state, or both. A golden age primitivist claims that 'the highest degree of excellence or happiness in man's life existed at the beginning of history' (Lovejoy and Boas, 1973: 2). The qualitative and quantitative change was for the worse, whether thought of as gradual (the golden age lapsing into silver) or sudden (the fall and expulsion from Eden). This type of primitivism's central normative metaphors are of a return (or its tragic impossibility) and the hoped-for dismantling or destruction of the elaboration which moved us away from the primary state. Its normative focus is on an ideal past. Golden age primitivism is in direct competition with theories or stories which use the same picture of history, but make the opposite value claim: that the qualitative and quantitative change was for the better.

We can now see that although human nature and golden age primitivism are analytically distinct, it is possible to hold both positions, or 
a position involving elements of both. Apart from archaeological and anthropological evidence, another way of supporting a characterisation of a golden age is to use claims about an uncorrupted human nature, which was fully expressed before whatever elaboration produced our current arrangements occurred. Or we might support a characterisation of human nature as wholly good with claims about how humans lived in a primary, natural or undistorted State. The implications of accepting golden age primitivism are various; we might for instance try to return to the golden age, whether individually or collectively; or lapse into quietist nostalgia; or take the ideal as reason for bitter rejection of the current world. Whatever practical conclusions anarchists are supposed to draw from their alleged primitivism, the critics' central assertions must be that anarchists hold such an idea of a past golden age or Eden, and use the metaphors of return and dismantling or destruction; and that this idea invalidates their theories because it is false in such a way as to make it useless as a norm. As with the accusation of human nature primitivism, there are three ways of defending anarchism against this accusation: first, to show that anarchists do not, in fact, share such an idea; next, to show that it is true; or, finally, to show that, although false, it is still useful as a norm. And, as above, I take the first path and disprove the critics' generalisation by counter-example. Godwin begins his scattered consideration of history by repeating the 'old observation that the history of mankind is little else than a record of crimes' (Godwin, 1985: 83). If we consider the continuous war, torture, slavery and despotism which historians record, we may believe that little has changed or will change:

An opinion has been extensively entertained 'that the differences of the human species in different ages and countries, particularly so far as relates to moral principles of conduct, are extremely insignificant and trifling; that we are deceived in this respect by distance and confounded by glare; but that in reality the virtues and vices of men, collectively taken, always have remained, and of consequence,' it is said, 'always will remain, nearly at the same point' (Ibid.: 156).

However, this opinion is shown to be false by 'a summary recollection of the actual history of our species' (Ibid.: 156-7) which, according to Godwin, shows 'man' gradually improving 'as an intellectual being' (Ibid.: 157). His deduction from the conjunction of this intellectual improvement with the motivating power of knowledge of the good (discussed above) is that human moral improvement has kept and will keep pace with it. 'Man in his original state' was 'a being capable of impressions and knowledge to an unbounded 
extent, but not having as yet received the one or cultivated the other' (Ibid.). Godwin contrasts the history of pain and oppression that he has noted with 'all that science and genius have effected' (Ibid.) and emphasises the examples of language and writing. Far from harking back to a golden age from which we have descended, Godwin pictures history as recording upward progress in knowledge and consequently in value.

The conclusion Godwin draws from this record of progress is that humans are 'susceptible of perpetual improvement' (Ibid.: 156, my emphasis). This derivation is surely invalid, but that is not the criticism we are dealing with here, and Godwin is only one of many who have made that perfectionist claim (see Passmore, 2000). Godwin, as an anarchist, is accused of golden age primitivism, but what he actually says is that:

There is no science that is not capable of additions; there is no art that may not be carried to a still higher perfection. If this be true of all other sciences, why not of morals? If this be true of all other arts, why not of social institution? ... This is the temper with which we ought to engage in the study of political truth. Let us look back, that we may profit by the experience of mankind; but let us not look back as if the wisdom of our ancestors was such as to leave no room for future improvement (Godwin, 1985: 163).

That is, he gives as explicit a rejection of golden age primitivism as could be expected from someone who had not had the criticism put to him. The central normative metaphors of golden age primitivism are of return, dismantling or destruction; Godwin's are of (perpetual) improvement and further building. Where its normative focus is an ideal past, his is an ideal future. So, we have our first counter-example to this second sense in which anarchists are supposed to be primitivists: Godwin was no more a golden age primitivist than he was a human nature primitivist.

We have already noted Kropotkin's interest in natural and social history. In Mutual Aid he treats the two as continuous, and moves from mutual aid amongst animals, to that among 'savages,' 'barbarians,' and in medieval cities, to mutual aid amongst 'ourselves.' This natural and social history has a double purpose; Kropotkin intends to show that mutual aid is a factor in evolution. That is, to show that one of the things which must be taken into account when explaining the facts of current animal and human nature, and their development, is mutual aid. According to this account, our current world cannot be explained only as the evolutionary result of ruthless individual struggle (as Huxley supposed). Secondly, Kropotkin intends to 
display and celebrate the successes and continuing existence of the tendency towards mutual aid, despite undeniable division, self-assertion and oppression. Kropotkin concludes Mutual Aid with two claims, one general and the other more specific. The general claim is that:

The animal species, in which individual struggle has been reduced to its narrowest limits, and the practice of mutual aid has attained the greatest development, are invariably the most numerous, the most prosperous, and the most open to further progress. The mutual protection which is obtained in this case, the possibility of attaining old age and of accumulating experience, the higher intellectual development, and the further growth of sociable habits, secure the maintenance of the species, its extension, and its further progressive evolution. The unsociable species, on the contrary, are doomed to decay (Kropotkin, 1969: 293).

Evolution by natural selection has given rise to a tendency to mutual aid, because that tendency is adaptive, while the opposite tendency is maladaptive. The more specific claim is that:

The periods where institutions based on the mutual-aid tendency took their greatest development were also the periods of the greatest progress in arts, industry, and science. In fact, the study of the inner life of the mediaeval city and of the ancient Greek cities reveals the fact that the combination of mutual aid, as it was practised within the guild and the Greek clan, with a large initiative which was left to the individual and the group by means of the federative principle, gave to mankind the greatest periods of its history - the ancient Greek city and the mediaeval city periods; while the ruin of the above institutions during the State periods of history, which followed, corresponded in both cases to a rapid decay (Ibid.: 296-7).

The expression of the mutual aid tendency has good consequences, and its eclipse by the equally real opposing tendency has bad ones, measured by human social progress and flourishing. In this second conclusion, Kropotkin certainly does claim that there have been better times than now (or rather, than the late nineteenth century). However, he does not locate these better times at the beginning of history or of a single value-gradient, either for the better or for the worse. He does not appear even to recognise the notion of a 
beginning to specifically human history, since he treats it as continuous with natural history. Instead, Kropotkin pictures history as a dialectical process between egalitarian mutual aid and hierarchical self-assertive tendencies and social forms, sometimes the one and sometimes the other gaining the upper hand. That first tendency, although now eclipsed, has not disappeared:

[n]either the crushing powers of the centralized state nor the teachings of mutual hatred and pitiless struggle ... could weed out the feeling of human solidarity, deeply lodged in men's understanding and heart, because it has been nurtured by all our preceding evolution (Ibid.: 292).

The continuing existence of this mutual aid tendency entitles us to a (cautious) optimism about the future. Again: the central normative metaphors of golden age primitivism are return and dismantling or destruction; its focus is an ideal past. Kropotkin does not recommend return to any earlier social form, but the expression of one continuing tendency of human life over another. He does recommend dismantling one set of social forms - states and capitalism - but he wants to replace it with another, better one, not to dig down to some simple or primary foundation. His focus is a better future, not an ideal past. So, we have our final counter-example: Kropotkin was also not a golden age primitivist.

As with my argument above against the accusation of human nature primitivism, it is unlikely that the partisans of this accusation literally and formally mean the generalisation 'all anarchists...'. And again, my counterexamples throw doubt on, but cannot completely disprove, the weaker claim they probably do mean. These interpretations of Godwin and Kropotkin are not intended as defences of their arguments. I have no brief here to show that either is right. All I need to show, and have shown, is that they do not hold the views attributed to them by the accusations of human nature or golden age primitivism. This must, at minimum, make us doubt that these accusations are true in general, and, I suggest, ought to make us reject them altogether. Anarchists are neither human nature nor golden age primitivists.

\section{Generalisations About Anarchism}

I want to emphasise that these negative claims are about generalisations. I have not argued that no anarchist is a primitivist: anarchism is various to the point of fragmentation, and some self-described anarchists may hold an idea of human nature as wholly pure and good, or admire and desire to emulate 'primitive' (primary, natural or foundational) social forms (see, for 
example, Zerzan, 1995). It is also open to future anarchists to do so. However, many anarchists, including two of the most important anarchist theorists, are not primitivists in either of these ways, and therefore being an anarchist does not entail being a primitivist. According to Sébastien Faure, 'There is not, and there cannot be, a libertarian Creed or Catechism' (in Woodcock, 1977: 62). However, if we imagine for a moment that there could be, it would not include a statement of primitivist belief. Nor would the imagined catechism include any particular claims about human nature. The point of giving two counter-examples to the accusation of human nature primitivism was to make the point more strongly than a single, possibly exceptional example could, but also to suggest that anarchists do not share some other, nonprimitivist account of human nature. Godwin and Kropotkin not only do not share the primitivist idea, they share no particular idea of human nature. For Godwin humans are rational and motivated by their judgement, have no innate bars to transformation through education, and perpetually improve. For Kropotkin, in contrast, humans are evolved creatures, related to the rest of the natural world, and as a result of that evolution have opposed tendencies toward different kinds of sociability. So, there is no orthodox anarchist view of human nature: even if accepting some set of claims is necessary if one is to be an anarchist in the ordinary sense of the term, that set does not include any claim about human nature. Similarly, the catechism would not include a particular view of the shape and moral direction of human history. For Godwin, history is a gradual upward process driven by the increase of knowledge; for Kropotkin, a dialectic of anarchic against hierarchical tendencies. Both focus more on the future than on the ideal past of the golden age primitivist, but where Godwin celebrates an inevitable and ideal future, Kropotkin merely argues for the possibility of a better one. So, again, even if an anarchist must accept some orthodox claims, they do not include a view of history. In short, anarchism cannot be characterised by particular positions on either human nature or history.

These re-readings of Godwin and Kropotkin have more general consequences for how we should think about anarchism. Both were intensely involved in major intellectual currents of their times. Godwin was shaped by nonconformist and Calvinist Christianity and by (one strand of) enlightenment thought; Kropotkin by the political and theoretical ferment which followed the publication of Origin of Species in 1859. So, anarchists are not, in general, the marginal or isolated figures they are sometimes painted. The conclusion that anarchists are not primitivists also has consequences for how we should think about anarchism. The force of primitivist arguments of both kinds is that they hold out the promise that, if only our current institutions and arrangements (however conceived) could be removed, then 
everything would be fine. Human nature primitivism promises that once some distorting influence is removed, real and good humanity will express itself; golden age primitivism, that once the elaboration of the decline or fall is removed, we will be left with a simple, good life; combinations of the two, that the distortion is the elaboration, and that once it is gone, we will return to the good and natural life with which we began. I call this powerful form of polemic 'post-apocalyptic,' for convenience and after the genre of fiction which imagines the aftermath of the destruction of current social forms and institutions. ${ }^{9}$ Post-apocalyptic theories, in general, propose a politics of absence: the absence of power, institutions, organisation and political compromise. Anarchists are not primitivists, and do not typically share the post-apocalyptic faith. An anarchist utopia is one specific social form among many possible ones, not merely the absence of states, or capitalism, or any of the other features of our current arrangements which anarchists criticise. Anarchists do not propose to remove politics or power to reveal something pure or primary beneath; rather, they reject some particular ways of organising power, and particular forms of politics, in favour of many alternative utopias. They claim that anarchic utopia is a possible social form, not that it is a golden age to which we might return, nor that it would be the result of the undistorted expression of a wholly good human nature.

Anarchists in general are neither human nature nor golden age primitivists, and therefore do not share what I have called the 'postapocalyptic' faith. This conclusion is important because it recovers some interesting thought, exemplified here by Godwin and Kropotkin, from blanket misrepresentation which too often leads to blanket dismissal. It is further important because, in making the case against the accusation of primitivism, we have had to articulate primitivism, which itself is too often dismissed without analysis. We are left with a more complex picture: first, of anarchist theory; second, of the history of our pictures of human nature and human history; third, of the political uses of such pictures.

Sam Clark is Lecturer in Philosophy in the Department of Politics, Philosophy, and Religion at Lancaster University. He developed the arguments in this paper in his book Living Without Domination (Ashgate 2007; paperback edition Routledge 2016). His more recent work is on the philosophies of autobiography, narrative, and self-realization. 


\section{Endnotes}

${ }^{1}$ This paper draws on chapter one of Samuel Clark, Living Without Domination: The Possibility of an Anarchist Utopia (Aldershot, 2007). I would like to thank the reviewers of this journal for their helpful comments on an earlier draft.

${ }^{2}$ For discussion of these readings, see Mark Philp, Godwin's Political Justice (Ithaca, 1986), especially Part One. The last interpretation, with its cultish overtones, has been popular amongst non-anarchist historians of anarchism: Isaac Kramnick, for instance, calls Godwin the 'prophet' of anarchism (Editor's Introduction to William Godwin, Enquiry Concerning Political Justice (3rd Ed. 1985), pp. 7-54. p. 7).

${ }^{3}$ John Stuart Mill and his father James seem to have held a similar antiHumean view that judgements about the truth, not just desires, can motivate. For them as for Godwin, this had the consequence of giving education and free discussion immense political import, since what people learned would give rise to action (see especially John Stuart Mill, Autobiography, Ed. Harold J. Laski (Oxford University Press: London, 1926) and On Liberty in John Gray (Ed.), On Liberty and Other Essays (Oxford University Press; Oxford, 1991), pp. 5-128). Thomas Scanlon's argument that reasons rather than desires are motivationally basic, in What We Owe to Each Other (Harvard University Press: Cambridge Mass., 1998), is a more recent contribution to this philosophic radical tradition. I hope to pursue this topic further elsewhere.

${ }^{4}$ Godwin later changed his mind about this conclusion, and asserted innate human goodness in the 1831 essay Thoughts on Man (in Mark Philp (ed.), Political and Philosophical Writings of William Godwin (6 vols. William Pickering: London, 1996), vol. 6, pp. 31-292). Even there, however, he emphasises the changeability of humans and our potential for good, grounded on the proper and private exercise of a shared rational capacity.

${ }^{5}$ see Avrich (1988); Kropotkin (1899); Miller (1976); (1987) and Woodcock and Avakumovi (1990).

${ }^{6}$ First published in book form in 1902, having previously appeared as a series of articles in the periodical Nineteenth Century. 
${ }^{7}$ And, in typical nineteenth-century terms, as high in a hierarchy of development.

${ }^{8}$ Peter Marshall has perhaps come closest to this exhaustive project. His examination of an extraordinary range of anarchist thought leads him to conclude that 'few anarchists believe in natural goodness' (1993: 643). Marshall also suggests, however, that 'Kropotkin comes closest' (Ibid.) to such a notion; I disagree, for the reasons given here.

${ }^{9}$ I do not mean to suggest that post-apocalyptic literature in general claims that everything would be fine after the disaster. Algis Budrys's Some WIII Not Die (1964), for instance, is extremely pessimistic; pat Murphy's The City, Not Long After (1990) offer both good (anarchist) and bad (militaristic) possibilities. For analyses of the apocalyptic trope in its usual home, science-fiction, see David Seed (2000).

\section{Bibliography}

Avrich, P. (1988) 'Kropotkin's Ethical Anarchism' in Anarchist Portraits Princeton: Princeton University press, pp. 53-78

Barber, B. (1972) Superman and Common Men Middlesex: Harmondsworth

Barry, N. (1991) 'Anarchism' in Nigel Ashford and Stephen Davies (Eds.) A Dictionary of Conservative and Libertarian Thought London: Routledge, pp. 4-7

Budrys, A. (1964) Some Will Not Die London: Mayflower-Dell

Chaney, N. (1990) Six Images of Human Nature Eaglewood Cliffs: Greyden

Clark, S. (2007) Living Without Domination: The Possibility of an Anarchist Utopia Aldershot: Ashgate

Dahl, R. (1989) Democracy and its Critics New Haven: Yale University Press

Dawkins, R. (1989) The Selfish Gene Oxford: Oxford paperbacks

Ellul, J. (1991) Anarchy and Christianity (Trans. G.W. Bromiley) Grand Rapids: William B. Eerdmans 
Faure, S. (1977) 'Extract from Encyclopédie Anarchiste' in George Woodcock (Ed.) The Anarchist Reader Glasgow: Fontana

Godwin, W. (1996) 'Thoughts on Man' in Political and Philosophical Writings of William Godwin Vol. 6, Mark Philp (Ed.), London: William Pickering, pp. 31-292

Godwin, W. (1992) Collected Novels and Memoirs of William Godwin Vol. I: Memoirs Pamela Clemit, Maurice Hindle and Marilyn Butler (Eds.), London: William Pickering

Godwin, W. (1986) The Anarchist Writings of William Godwin Peter Marshall (Ed.), London: Freedom Press

Godwin, W. (1985) Enquiry Concerning Political Justice (3rd Ed.) Isaac Kramnick (Ed.), London: Penguin

Horowitz, I. (1964) The Anarchists New York: Dell

Joll, J. (1979) The Anarchists (2nd Ed.) London: Routledge

Kropotkin, P. (1995) The Conquest of Bread and Other writings M.S. Shatz (Ed.), Cambridge: Cambridge University press

Kropotkin, P. (1989) Mutual Aid: A Factor of Evolution Montréal: Black Rose Books

Kropotkin, P. (1911) 'Anarchism' from The Encyclopedia Britannica, 11th Ed. in M.S. Shatz (Ed.) The Conquest of Bread and Other Writings Cambridge: Cambridge University Press

Kropotkin, P. (1899) Memoirs of a Revolutionist (2 Vols) London: Smith, Elder \& Co.

Loptson, P. (1995) Theories of Human Nature Peterborough Ontario: Broadview

Lovejoy, A. O. and Boas, G. (1973) Primitivism and Related Ideas in Antiquity New York: Octagon 
Marshall, P. (1993) Demanding the Impossible: A History of Anarchism rev. edn, London: Fontana

Marshall, P. (1986) 'Editor's Introduction' in W. Godwin (1986) The Anarchist Writings of William Godwin Marshall, Peter (Ed.), London: Freedom Press, pp. 9-48

Marshall, P. (1984) William Godwin New Haven: Yale University Press

Mill, J. S. (1991) 'On Liberty' in John Gray (Ed.) On Liberty and Other Essays Oxford: Oxford University Press

Mill, J. S. (1926) Autobiography Harold J. Laski (Ed.), London: Oxford University Press

Miller, M. A. (1976) Kropotkin Chicago: University of Chicago Press

Morland, D. (1997) Demanding the Impossible? Human Nature and Politics in Nineteenth-Century Social Anarchism London: Continuum

Murphy, P. (1990) The City, Not Long After New York: Macmillan

Passmore, J. (2000) The Perfectibility of Man (3rd Ed.) Indianapolis: Liberty Fund

Philp, M. (1986) Godwin's Political Justice Ithaca: Cornell University Press

St Clair, W. (1989) The Godwins and the Shelleys: The Biography of a Family London: Faber and Faber

Scanlon, T. (1998) What We Owe to Each Other Cambridge Mass.: Harvard University Press

Scruton, R. (1983) A Dictionary of Political Thought London: Pan

Seed, D. (2000) Imagining Apocalypse: Studies in Cultural Crisis Houndmills: Macmillan

Stevenson, L. and Haberman, D. L. (1998) Ten Theories of Human Nature (3rd Ed.) New York: Oxford University Press 
Todes, D. P., (1978) ‘Darwin's Malthusian Metaphor and Russian Evolutionary Thought, 1859-1917' Isis Vol. 78, pp. 537-51

Woodcock, G. and Avakumovi, I. (1990) Peter Kropotkin: From Prince to Rebel Montréal: Black Rose Books

Woodcock, G. (1977) The Anarchist Reader Glasgow: Fontana

Woodcock, G. (1946) Biographical Study London: Porcupine Press

Zerzan, J. (1995) 'Future primitive' available URL at http://www.primitivism.com/future-primitive.htm, date accessed 11/3/08 